fees at all. The implications are plain. If the British government means what it says about the importance of training for the future health of British industry, it must make the cost of training fees paid out of a taxpayer's pocket tax-deductible. And it must use some of the $£ 50$ million a year it will save on the industrial training boards to help those out of work to acquire new skills.

In the past two years, the British government has been outwardly resolute in sticking to the monetarist guns that have made the present recession the painful phenomenon it is. The government has been alternatively praised for courage and pilloried for pigheadedness. In reality, it has followed an intermediate course - nationalized industries such as British Leyland and British Steel have been saved from collapse by taxpayers' money. Universities and other institutions of higher education have been exposed more directly to the cold winds of economic change, and like many parts of British manufacturing industry, are running well below capacity. They too will emerge transformed from the present slump. One possible and desirable outcome would be that at least some of them should be more directly involved with continuing education. If the government means what it has been saying these past several months about the importance of retraining and about its respect (or at least lack of enmity) for higher education, and because the falling inflation rate suggests that the time is fast approaching when reflationary policies will again be necessary, it will be absurd if this opportunity is let slip.

\title{
How to make dreams untrue
}

Although the hunt for the philosopher's stone has long since been abandoned, the hunt for its antidote, the material that turns everything into lead, continues apace, most successfully in the dealings between the British government and the nationalized industries for which it is responsible. This is the chief lesson to be drawn from the report of the House of Commons Select Committee on Energy (see page 621) on the new British nuclear energy programme. The committee plainly found its inquiry into the rights an wrongs of the proposal and infuriating experience. The British government chose not to pass on to the committee the advice provided by the Central Policy Review Staffs on the wisdom of building two reactors of the advanced gas-cooled type, thus confirming the widespread understanding that the advice was hostile to the project - and the belief that when British governments extol the benefits of open government, they are thinking of governments other than themselves. The Department of Energy, ostensibly in charge of the substantial commitment of resources entailed by the nuclear programme, is convicted of incompetence by its evidence in the House of Commons. The Central Electricity Generating Board, the nationalized electricity utility which is the constructor and operator of nuclear plants south of the Scottish border, is accused not of excusable incompetence but of unforgivable deviousness. When all the dust has settled, the chief casualty of the committee's forthright report will be the British nuclear programme, fanned to life only in 1979 from the embers of a decade's neglect.

Even after due allowance is made for the way in which select committees these days have to shout to be heard above the reports that flood from their competitors, the language used by the Select Committee on Energy will surprise many of those at whom the complaints are levelled. For the committee's chairman and deputy chairman are both members of the now defunct Select Committee on Science and Technology which, over the years, has been one of the most consistent cheerleaders for nuclear power in Britain. What has gone wrong, the luckless targets of the report will be asking? The answer is that they have compromised a good cause by arrogance, fecklessness (which is a synonym for conscious laziness) and a failure to understand what they are for. In the short run, only they may suffer. Further ahead, taxpayers (and electricity consumers) will also be the losers.

The problem of nuclear power in Britain is by now a problem in national mythology. Ever since the Tizard mission to Washington in 1941, the popular belief in Britain has been that nuclear fission was invented ("discovered" is too passive a word) in the land of Newton. The Ottawa Agreement in 1944 merely codified what most people knew, for which reason it followed as night does day that there should be a truly Britishnuclear cxplosion (in 1948) and, now, a nuclear deterrent (called Trident) whose design may be American but whose construction is beyond question British. The commercial exploitation of nuclear power in the past quarter of a century has been a cross between a fairy story and a nightmare. From time to time, radical innovations of technology have been announced, have been widely advertised to an unsuspecting press and then have been allowed to run into the sand because nobody cared about them in the sense of knowing that not merely his reputation but his pension (index-linked) would depend on the realization of his promises to the public. To everybody's surprise, however, the nuclear reactors built in the first heady days of the nuclear enterprise (with natural uranium as fuel and graphite as a moderator) are mostly still working well and helping to reduce the price paid by electricity consumers.

The select committee's forgivable irritation has plainly led it to complain most vociferously at those who sought unsuccessfully to mislead it - the Central Electricity Generating Board is the worst offender. The issue, the committee says, is whether the board can possibly be right in pretending that the nuclear power stations it plans to order in the coming decade will be economical devices for generating electricity when there is so much evidence that the board's assumptions are either untested or untestable. All kinds of questions arise. Can the board be right in guessing that the cost of producing coal (the obvious alternative to uranium) will increase by between 2.5 and 3 per cent a year in the foreseeable future? Can it be believed in quoting capital costs for building the simplest structures when it has so mismanaged the oil-fired power station still painfully half complete on the south bank of the Thames Estuary? Is it, indeed, possible to consider seriously the figures produced by the board and others, purporting to quote future electricity generating costs, if none of the interested parties turns a hair when it turns out that the estimates are wrong, and that the consumers of electricity must pay the difference? For all its rhetoric, the committee would have had a more telling case if it had been able to specify the premises on which utilities (such as the Central Electricity Generating Board) might set out to calculate the future cost of electricity. The truth is, of course, that in the real world there are none that carry conviction. What happens if there is, in the end, a war in the Middle East? It would be too late, then, to call the committee back into session.

With luck, such a drastic course will not be necessary. The committee has done what it needs to do for the decade ahead. It has thrown a spanner in works that were not working. The recommendation that the United Kingdom Atomic Energy Authority should be the chief agent of technological change in the nuclear industry, concerned principally with fast reactors and with fusion, is to be welcomed. The plea that the Department of Energy should somehow equip itself to understand the policies with which it pretends to grapple is right, but will quickly be forgotten with the connivance of the department. The crux of the issue, with which even this loudspoken committee has not come to grips, is that there is no mechanism in the present arrangement for the sponsorship of nuclear or any other kind of power that will allow that the consumer of the electricity should be king. The present British government has widely advertised its wish to reduce the public sector's borrowing requirement by inducing private investors to share some of the risk. Is it not time that it sold the Central Electricity Generating Board to somebody with a long purse - or better still, a conscience? The committee's irritation has led it correctly to pillory the board. It should go on to define criteria by which all such boards should measure their duty. 